\title{
SEASONAL SPECTRAL SEPARABILITY OF SELECTED GRASSES: CASE STUDY FROM THE KRKONOŠE MTS. TUNDRA ECOSYSTEM
}

\author{
L. Črvená ${ }^{1, *}$, L. Kupková ${ }^{1}$, M. Potůčková ${ }^{1}$, J. Lysák $^{1}$ \\ ${ }^{1}$ Department of Applied Geoinformatics and Cartography, Faculty of Science, Charles University, Albertov 6, Prague 2, Czech
Republic - (lucie.cervena, lucie.kupkova, marketa.potuckova, jakub.lysak)@ @atur.cuni.cz
}

Commission III, WG III/4

KEY WORDS: laboratory spectroscopy, image spectroscopy, Krkonoše Mts., grasses, tundra, spectral separability, seasonal changes

\begin{abstract}
:
This paper focuses on spectral separability of closed alpine grasslands dominated with Nardus stricta and competitive grasses Calamagrostis villosa and Molinia caerulea in the relict arctic-alpine tundra located in the Krkonoše Mountains National Park, Czech Republic. The spectral data were acquired and compared at three levels: spectra of a single layer of leaves measured with the ASD FieldSpec4 Wide-Res spectroradiometer coupled with a contact probe in a laboratory (leaf level), canopy spectra measured in a field with the same spectroradiometer using the fiber optic cable with a pistol grip (canopy level), and hyperspectral image data acquired by Nano-Hyperspec ${ }^{\circ}$ fastened to the DJI Matrice 600 Pro drone (image level). All the measurements were repeated three times during the 2019 vegetation season - in June, July and August. Using the methods of analysis of variance and Welch's (unpaired) t-test, it was proven that there were differences in the results for all three spectra sources. But in general, for each combination of species and each data source a suitable date and intervals of the spectral bands for species separation exist. The most suitable term for data acquisition in order to differentiate all the species is July. At the leaf level, the best species separability was observed in the near-infrared and shortwave infrared spectral ranges. At the canopy and image levels, the visible bands are of higher importance for discriminating the species.
\end{abstract}

\section{INTRODUCTION}

The relict arctic-alpine tundra located in the Krkonoše Mountains National Park, the Czech Republic $\left(51^{\circ} \mathrm{N}, 16^{\circ} \mathrm{E}\right.$, altitude above $1,350 \mathrm{~m}$ a. s. 1.) is a unique ecosystem combining arctic, alpine and middle European flora and fauna. Geologically, the origin of Krkonoše Mts. was in the period of the Proterozoic and Early Palaeozoic eras, but many later processes gradually transformed the original appearance of the Krkonoše Mts. The most important process for evolution of so called relict arctic-alpine tundra was the Pleistocene glaciations, when the Scandinavian glacier reached to the vicinity of the northern foothills of the Krkonoše Mts. and some local glaciers developed in the valleys. The polar tundra spread in the nonglaciated parts in this period of the very cold (periglacial) climate. At the same time, the increasing extent of glaciation of the Alps resulted in the descent of the alpine tundra from the alpine slopes to lower altitudes and towards the north to the Czech basin, where the alpine tundra mixed with the polar tundra and on the highest mountain ridges persists to our days. (Kociánová et al., 2015)

Nowadays, the average annual temperature in the Krkonoše mountains tundra is around $+1.6^{\circ} \mathrm{C}$, strong north-western winds are typical. Mean annual rainfall is about $1,400 \mathrm{~mm}$, snow lies on the ground in average more than 180 days (Soukupová et al., 1995). Thus, the vegetation season is very short (June to September). Different management schemes have been applied in the tundra grasslands over the last 100 years; they evolved from grazing and cutting to the high level of protection - zone without human interference. Due to that as well as due to the climate change, some developments in vegetation composition are being recorded: closed alpine grassland dominated with Nardus stricta are threatened by the spread of competitive grasses Calamagrostis villosa (Hejcman et al., 2009) and Molinia caerulea (Hejcman et al., 2010). Also, the expansion of Pinus mugo scrub (Štursa and Wild, 2014) and Norway spruce (Treml et al., 2012) is observed. Further changes in the vegetation composition are caused by direct human influence connected to tourism such building of alkaline paved roads, disturbances around chalets (eutrophication) or soil erosion (Vítek et al., 2012). Therefore, a detailed mapping and monitoring of the ongoing changes are necessary to select the appropriate ways to protect the vulnerable communities (nonintervention management versus selected management practise - e.g. grazing). Remote sensing - laboratory and image spectroscopy - proved to be an effective tool for detailed mapping and for differentiating tundra vegetation species or communities. It was successfully used in arctic tundra regions (e. g. Beamish et al., 2017; Bratsch et al., 2016; Davidson et al., 2016) as well as in the Krkonoše Mts. (Kupková et al., 2017; Marcinkowska-Ochtyra et al., 2018; Suchá et al., 2016). However, improving classification accuracy of some specific species is still a challenging task. In order to carry out effective monitoring, i.e. to minimise time for data acquisition and processing and maximise the classification accuracy, it is necessary i) to find the most suitable phenology phase when the spectra of the observed species differ the most and ii) to identify wavelengths which are crucial for the species separability and

\footnotetext{
* Corresponding author
} 
which should be therefore included in the acquired remote sensing data.

This paper focuses on spectral separability of closed alpine grasslands dominated with Nardus stricta and competitive grass species Calamagrostis villosa and Molinia caerulea. The main research questions are:

1) Are there the differences in the spectral reflectance of the selected species? How do the differences change during the season?

2) Is it possible to get the same results/differences using spectral data on various scale levels - green leave spectra measured by the spectroradiometer ASD FieldSpec4 Wide-Res coupled with a contact probe in a laboratory (leaf level), canopy spectra measured by the same spectroradiometer using the fiber optic cable with a pistol grip in a field (canopy level) and hyperspectral image data acquired by Nano-Hyperspec ${ }^{\circledR}$ fastened to the DJI Matrice 600 Pro drone (image level)?

\section{DATA AND METHODS}

\subsection{Data}

The three above mentioned species were studied: Nardus stricta (N. S.) and competitive grasses Calamagrostis villosa (C. V.) and Molinia caerulea (M. C.) - see Figure 1. All three species belong to the family Poaceae. Nardus stricta, known also as matgrass, is strongly tufted grass and usually grows to maximal heights of $40 \mathrm{~cm}$. The stems are stiff and hard, the leaves are gray-green, thin and rough. Calamagrostis villosa or also called as reedgrass is up to $1.2 \mathrm{~m}$ high, the leaves are usually $4-10 \mathrm{~mm}$ wide, grass-green, smooth, the knees are often hairy. Molinia caerulea, purple moor-grass, is very resistant grass, also up to $1.2 \mathrm{~m}$ high with light-green colour of leaves. It prefers sunny and moist locations. (Kubát and Bělohlávková, 2002)

The spectral measurements of studied grasses were acquired during three field campaigns of the 2019 vegetation season, namely on $14^{\text {th }}-19^{\text {th }}$ June, $10^{\text {th }}-12^{\text {th }}$ July and $14^{\text {th }}-16^{\text {th }}$ August.

Twelve plots per one species per date (all together $12 \times 3 \times 3$ plots) were measured by the spectroradiometer ASD FieldSpec 4 Wide-Res with the spectral range $350-2,500 \mathrm{~nm}$ coupled with a pistol grip (Figure 2). The $99 \%$ Spectralon ${ }^{\circledR}$ white reference was measured before each plot measurement. Canopy spectra were measured from the height of approximately $50 \mathrm{~cm}$ above the canopy - every plot was measured three times and afterwards a median spectrum was calculated. Unfortunately, some spectra had to be removed from further analyses due to obvious errors (a lack of cloud free days in the study area makes spectral measurements in the field quite challenging).

Small parts of the biomass (square $10 \mathrm{~cm} \times 10 \mathrm{~cm}$ ) from the same twelve plots per one species per date (108 samples) were put into the zip lock bags and placed into cooling box, which was taken to the laboratory, where the biomass was sorted to green leaves and necromass. Selected green narrow leaves were arranged beside each other (slightly overlapping) on a spectrally black surface to create a consistent layer to fill in the field of view of the ASD plant contact probe (spot size $10 \mathrm{~mm}$ ). For the Calamagrostis villosa and Molinia caerulea measurements, the leaves were laid with adaxial sides facing up. Every sample was measured in five positions from the apex to the base parts of the leaves by the plant contact probe coupled with the spectroradiometer ASD FieldSpec4 Wide-Res (Figure 2). Afterwards a median spectrum was calculated.
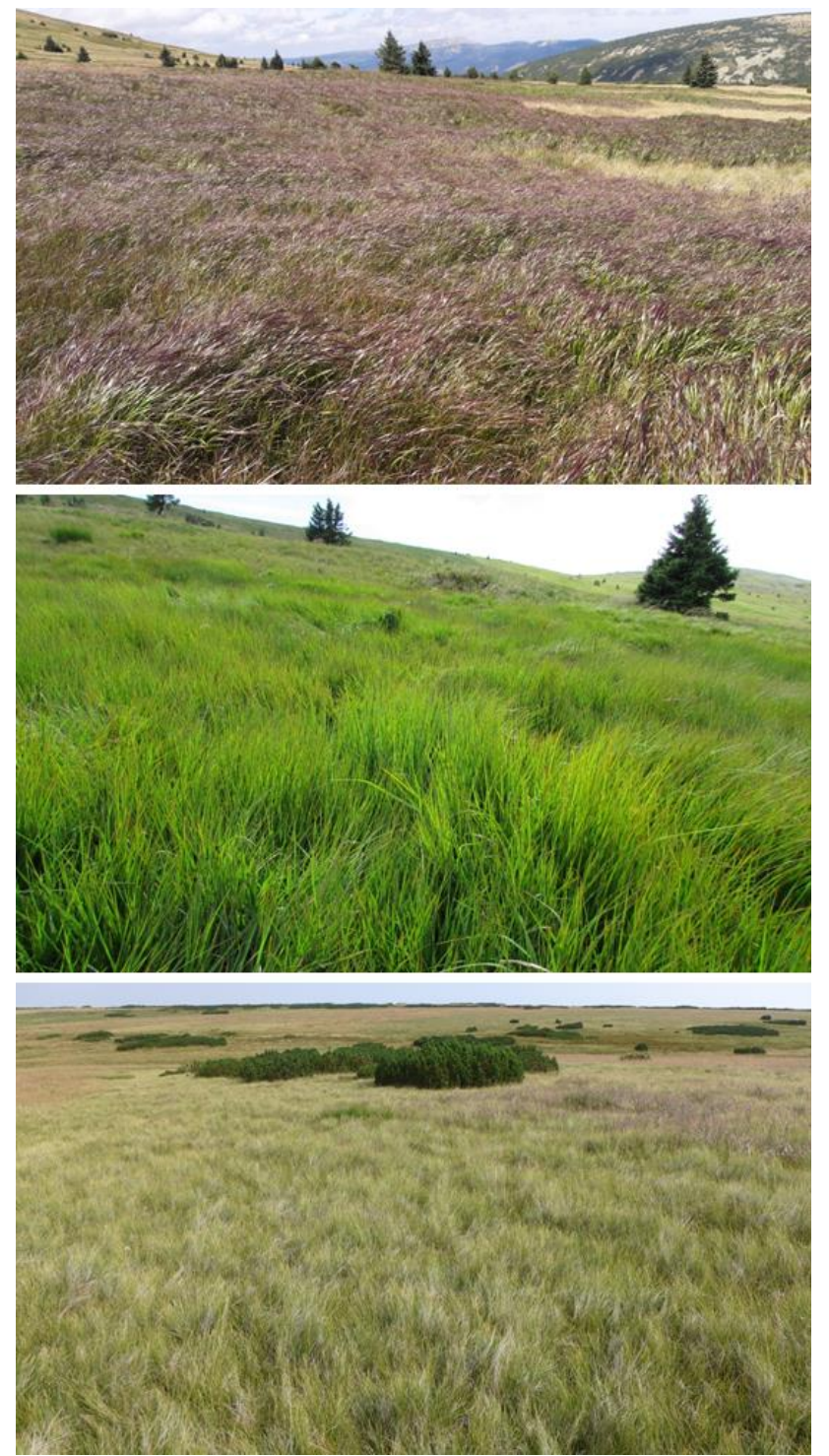

Figure 1. Calamagrostis villosa (up), Molinia caerulea (middle) and Nardus stricta (bottom) at the beginning of August

The third type of spectral data was spectra extracted for 36 random points per species per date $(36 \times 3 \times 3=324$ pixels $)$ from hyperspectral images acquired by Headwall Nano-Hyperspec $\mathbb{}$ fastened to the DJI Matrice 600 Pro drone (Figure 2). The flight high was $68.9 \mathrm{~m}$ above the terrain to ensure ground sampling distance of the data $3 \mathrm{~cm}$. The flights in June and August were carried out in sunny weather, so the exposure time were 4 or 5 $\mathrm{ms}$, frame period $6 \mathrm{~ms}$ and the flight speed $5 \mathrm{~m} / \mathrm{s}$ in both cases. The flight in July was carried out under a constant cloud cover, so the exposure time was $9 \mathrm{~ms}$, frame period $10 \mathrm{~ms}$ and the flight speed $3 \mathrm{~m} / \mathrm{s}$. The scanned area had an extent of $100 \mathrm{~m} \mathrm{x}$ $100 \mathrm{~m}$. To achieve $40 \%$ sidelap, 10 flight lines were needed to cover the entire area. The radiometric corrections were performed using the portable $3 \mathrm{~m} \times 3 \mathrm{~m}$ fabric target placed in the scanned area (Group 8 Technology, Inc., Provo, UT, USA) in the Headwall SpectralView - Hyperspec v3.1.0 software. The data cube consists of 270 bands, with wavelength ranging from 400 to $1,000 \mathrm{~nm}$. 

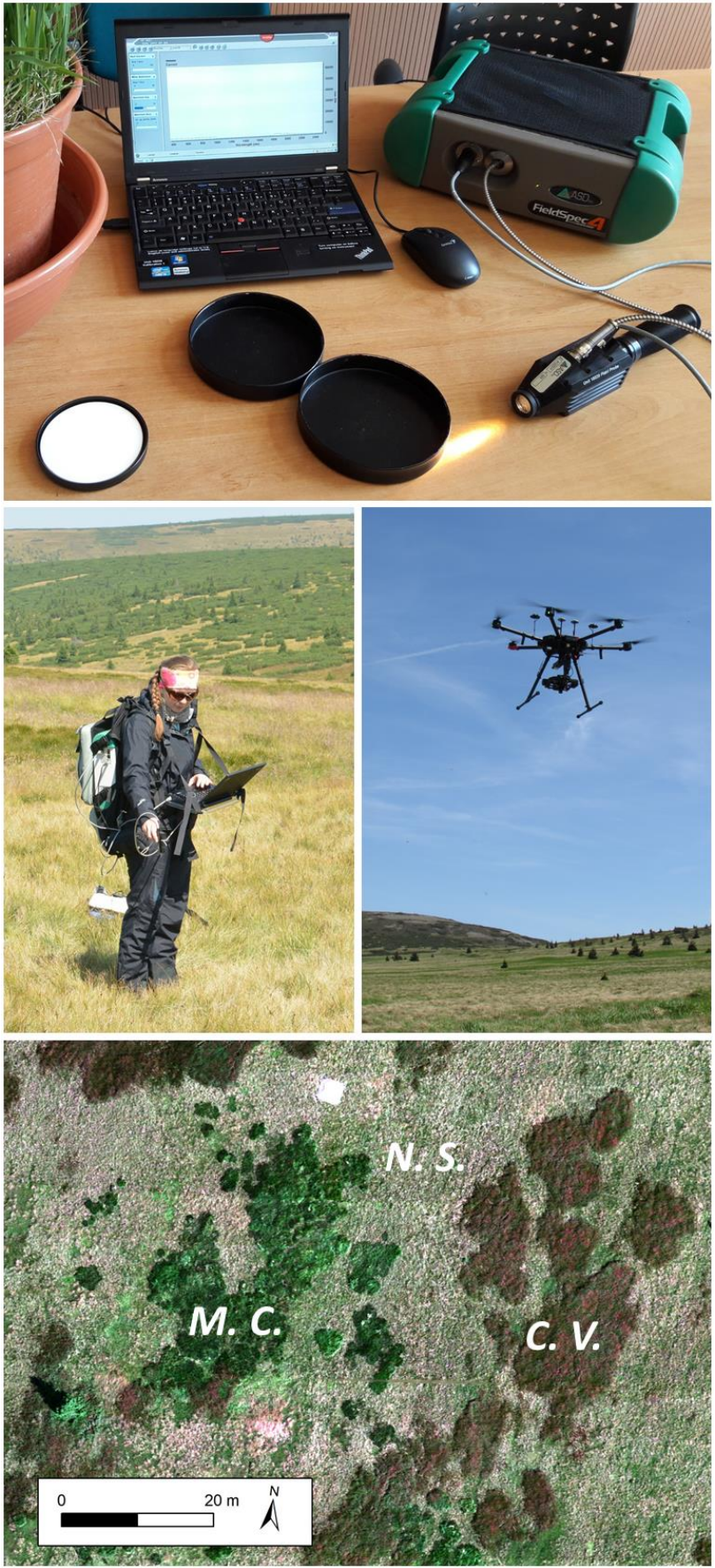

Figure 2. Instruments used to collect the spectral data: ASD FieldSpec4 Wide-Res coupled with a contact probe (up), the same spectroradiometer coupled with a pistol grip in a field (middle left) and Nano-Hyperspec ${ }^{\circledR}$ fastened to the DJI Matrice 600 Pro drone (middle right) with an example of the true colour composite of a part of the study area taken on $15^{\text {th }}$ August 2019, C. V. - Calamagrostis villosa; M. C. - Molinia caerulea, N. S. - Nardus stricta (bottom)

The geometric corrections were performed in the Headwall SpectralView - Hyperspec v3.1.0 and ArcGIS for desktop software. The manual addition of tie points and developing our own script to mosaic the data in ArcGIS for desktop were necessary to reach acceptable root mean square error (RMSE) on ground control points (RMSE about $0.1 \mathrm{~m}$ ). To compare, using the Headwall software, RMSE of about $2 \mathrm{~m}(!)$ was achieved. More details about geometric and radiometric corrections of the acquired hyperspectral images can be found in Červená et al. (2020).

\subsection{Methods}

Firstly, analysis of variance (ANOVA) was computed for each band to find out whether at least one species reflectance significantly differs from others in the given date and using the given spectral measurement method (rejecting the null hypothesis). The null hypothesis is that all three species have the same reflectance at the specified wavelength. The null hypothesis is rejected when the p-value is less than a prespecified significance level which was set to 0.05 . ANOVA was computed in a "for" loop for every wavelength and all the pvalues were saved and visualised (Figure 3).

To examine which species differ from each other in the given time period, Welch's (unpaired) t-test was carried out for each two species combinations. P-values were plotted in the graph; however, the interpretations of these graphs are very difficult. Therefore, the wavelengths were grouped into ten intervals which correspond to main characteristics of vegetation spectral curves:

$$
\begin{array}{ll}
\text { - } & 400-500 \mathrm{~nm} \text { (blue) } \\
\text { - } & 501-600 \mathrm{~nm} \text { (green) } \\
\text { - } & 601-680 \mathrm{~nm} \text { (red) } \\
\text { - } & 801-800 \mathrm{~nm} \text { (red edge) } \\
\text { - } & 1,001-1,350 \mathrm{~nm} \text { (near-infrared) } \\
\text { - } & 1,351-1,550 \mathrm{~nm} \text { (atmospher-infrared) } \\
\text { - } & 1,551-1,750 \text { (shortwave-infrared) } \\
\text { - } & 1,751-2,100 \text { (atmospheric water absorption) } \\
\text { - } & 2,101-2,300 \text { (shortwave-infrared). }
\end{array}
$$

Wavelengths shorter than $400 \mathrm{~nm}$ and longer than 2,300 nm were excluded from analyses due to the noise present in the data. The interval boundary at $1,000 \mathrm{~nm}$ was added because of the Headwall Nano-Hyperspec ${ }^{\circledR}$ data ending at this wavelength. The median $\mathrm{p}$-values were calculated for each of the intervals and compared among the instruments/the scale levels and among the studied acquisition dates (Table 1).

All the computations were performed in the $\mathrm{R}$ software. The visualisations of the results were prepared in the Microsoft Excel.

\section{RESULTS AND DISCUSSION}

Analysis of variance (Figure 3) shows that the best separability among all studied species was reached on the image level

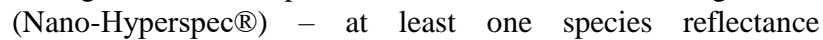
significantly differs from others at all the wavelengths from 400 to $1,000 \mathrm{~nm}$ in all three phenology phases. On contrary, at the canopy level (field spectra) there are more bands where species have similar reflectance - obviously these are the atmospheric water absorption bands and in addition some bands in visible (June) and red edge and near-infrared (July) parts of the spectrum. The worse separability based on the reflectance at the canopy level can be also influenced by fewer measurements for some species and dates (Calamagrostis villosa: only six spectra in June and eight in August could be used). We can find less separable bands among species in visible and red-edge parts of the spectrum and around 1,900 $\mathrm{nm}$ also at the leaf level (contact probe). 
Table 1 shows median p-values of Welch's (unpaired) t-test for grouped spectral intervals. The best wavelength interval for species separation at the image level is between 501 and $600 \mathrm{~nm}$ (green band; all the p-values are lower than 0.05) but also other two visible bands give very good results. The worst wavelength interval regarding species separability is in the near-infrared part of the spectrum (especially the last one for image level: $801-1,000 \mathrm{~nm}$ ) which can be caused by higher amount of noise in these bands. Similar results can be observed in the field spectral data (canopy level) - the best wavelength intervals to discriminate among the species are located primarily in green, red and red edge, but good results are also in near-infrared (801-1,000 nm) part of the spectrum. On the other hand, at the leaf level, the species are not separable using visible bands while near-infrared and shortwave infrared bands play the main role. The differences between leaf level and the other two levels are expectable as only the green leaves are measured by the contact probe but at the canopy and image levels the present dry mass strongly influences the resulting reflectance.

According to Table 1 also the best dates for discriminating the species can be determined. The best date to discriminate Nardus stricta at the leaf level is July. In June it has very similar reflectance to Calamagrostis villosa in the near-infrared and shortwave infrared bands and in August it is close to Molinia caeruella in visible and near-infrared bands. However, as mentioned above, at the canopy level necromass considerably influences the resulting reflectance. Thus, there are problems with separation of Nardus stricta and Molinia caerulea in June because both species contain a lot of necromass at the beginning of the season. At the end of the season Nardus stricta can be confused with Calamagrostis villosa in all bands from red edge to shortwave infrared. A very similar trend as at the canopy level can be seen for Nardus stricta also at the image level - it means that it can be detected better in July than in other months because of the similarity to Molinia caerulea in June and Calamagrostis villosa in August at longer wavelengths. For separation of Molinia caerulea and Calamagrostis villosa, which are visually more similar, June seems to be the best date (Calamagrostis villosa starts to grow earlier than Molinia caerulea at the beginning of the season). Nevertheless, August gives also the good results in separation of these two species at the canopy and image levels, while spectra from July are not very distinguishable especially at the longer wavelengths because both grasses are high, dense and green. The indistinguishability of Molinia caerulea and Calamagrostis villosa in the visible bands is observed at the leaf level in all three dates what is probably given by the similar colours and structures of the measured leaves.
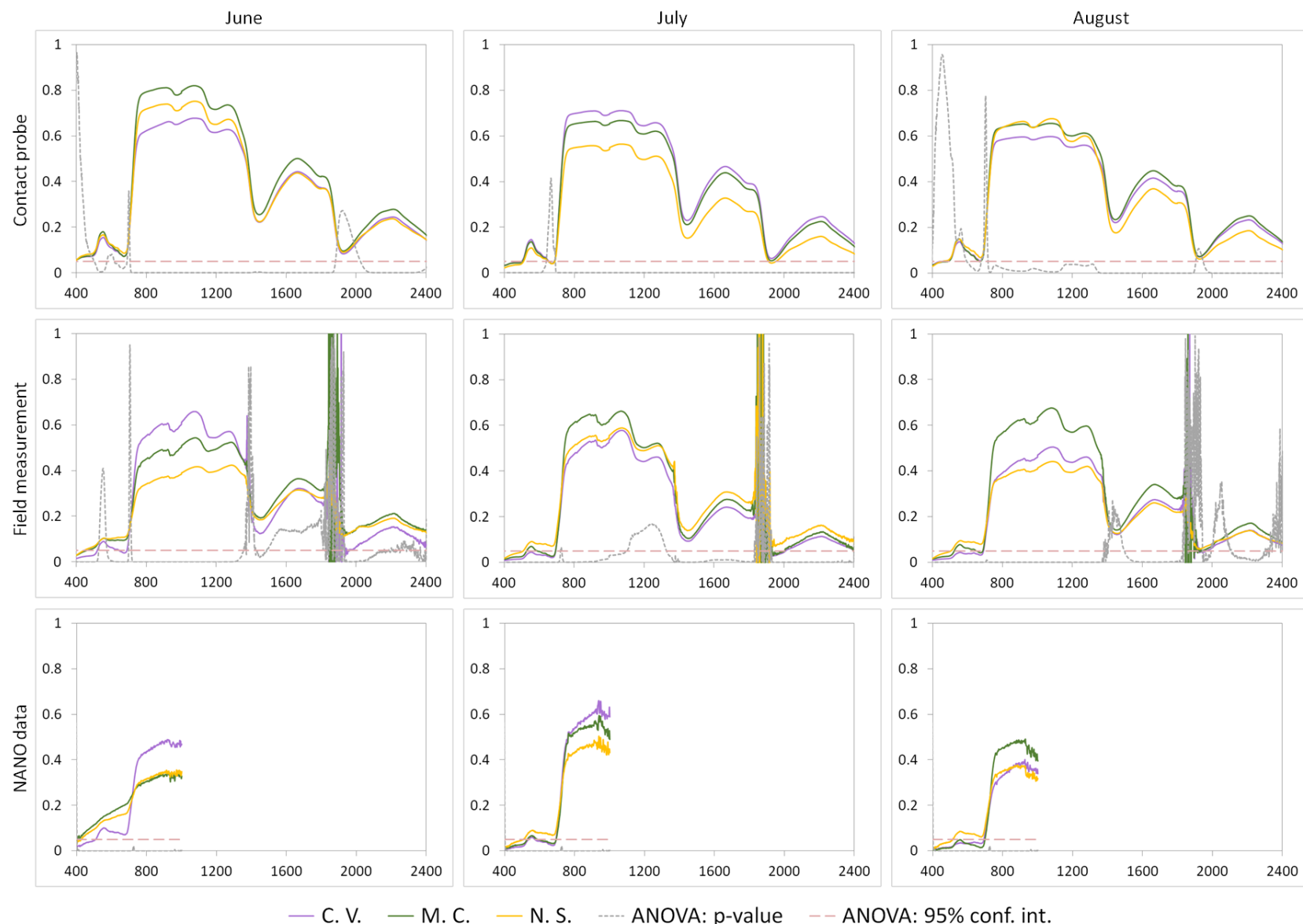

- C. V. - M. C.

N.S.

ANOVA: p-value

ANOVA: $95 \%$ conf. int.

Figure 3. Median spectra and p-values of ANOVA for each species (C. V. - Calamagrostis villosa; M. C. - Molinia caerulea, N. S. - Nardus stricta), spectral measurement method and date. Horizontal axis is the wavelength in nanometres, vertical axis the p-value and reflectance. 


\begin{tabular}{|c|c|c|c|c|c|c|c|c|c|}
\hline & \multicolumn{3}{|c|}{ June } & \multicolumn{3}{|c|}{ July } & \multicolumn{3}{|c|}{ August } \\
\hline LEAF level & N.S.C.V.V. & N.S.-M.C. & C.V.-M.C. & N.S.-C.V. & N.S.-M.C. & C.V.-M.C. & N.S.-C.V. & N.S.-M.C. & C.V.-M.C. \\
\hline $400-500 \mathrm{~nm}$ & 0.154 & 0.141 & 0.722 & 0.000 & 0.000 & 0.401 & 0.583 & 0.614 & 0.776 \\
\hline $501-600 \mathrm{~nm}$ & 0.039 & 0.298 & 0.005 & 0.000 & 0.000 & 0.132 & 0.139 & 0.500 & 0.254 \\
\hline $601-680 \mathrm{~nm}$ & 0.038 & 0.042 & 0.632 & 0.237 & 0.005 & 0.261 & 0.027 & 0.027 & 0.723 \\
\hline $681-800 \mathrm{~nm}$ & 0.011 & 0.001 & 0.000 & 0.000 & 0.000 & 0.003 & 0.111 & 0.276 & 0.031 \\
\hline $801-1000 \mathrm{~nm}$ & 0.005 & 0.001 & 0.000 & 0.000 & 0.000 & 0.001 & 0.008 & 0.787 & 0.032 \\
\hline $1001-1350 \mathrm{~nm}$ & 0.054 & 0.000 & 0.000 & 0.000 & 0.000 & 0.001 & 0.035 & 0.398 & 0.030 \\
\hline $1351-1550 \mathrm{~nm}$ & 0.743 & 0.001 & 0.001 & 0.000 & 0.000 & 0.000 & 0.000 & 0.000 & 0.019 \\
\hline $1551-1750 \mathrm{~nm}$ & 0.527 & 0.000 & 0.000 & 0.000 & 0.000 & 0.000 & 0.000 & 0.000 & 0.007 \\
\hline $1751-2100 \mathrm{~nm}$ & 0.571 & 0.021 & 0.007 & 0.000 & 0.000 & 0.000 & 0.000 & 0.000 & 0.112 \\
\hline $2101-2300 \mathrm{~nm}$ & 0.350 & 0.000 & 0.001 & 0.000 & 0.000 & 0.000 & 0.000 & 0.000 & 0.015 \\
\hline CANOPY level & N.S.-C.V. & N.S.-M.C. & C.V.-M.C. & N.S.-C.V. & N.S.-M.C. & C.V.-M.C. & N.S.-C.V. & N.S.-M.C. & C.V.-M.C. \\
\hline $400-500 \mathrm{~nm}$ & 0.000 & 0.436 & 0.000 & 0.000 & 0.000 & 0.000 & 0.000 & 0.000 & 0.000 \\
\hline $501-600 \mathrm{~nm}$ & 0.001 & 0.773 & 0.016 & 0.000 & 0.000 & 0.000 & 0.000 & 0.000 & 0.000 \\
\hline $601-680 \mathrm{~nm}$ & 0.000 & 0.361 & 0.000 & 0.000 & 0.000 & 0.039 & 0.000 & 0.000 & 0.005 \\
\hline $681-800 \mathrm{~nm}$ & 0.001 & 0.003 & 0.036 & 0.241 & 0.002 & 0.002 & 0.452 & 0.001 & 0.001 \\
\hline $801-1000 \mathrm{~nm}$ & 0.001 & 0.002 & 0.029 & 0.789 & 0.004 & 0.004 & 0.125 & 0.000 & 0.001 \\
\hline $1001-1350 \mathrm{~nm}$ & 0.001 & 0.005 & 0.157 & 0.274 & 0.385 & 0.042 & 0.090 & 0.000 & 0.004 \\
\hline $1351-1550 \mathrm{~nm}$ & 0.017 & 0.472 & 0.016 & 0.002 & 0.014 & 0.186 & 0.751 & 0.022 & 0.119 \\
\hline $1551-1750 \mathrm{~nm}$ & 0.725 & 0.096 & 0.114 & 0.007 & 0.112 & 0.092 & 0.439 & 0.001 & 0.025 \\
\hline $1751-2100 \mathrm{~nm}$ & 0.041 & 0.484 & 0.007 & 0.001 & 0.015 & 0.192 & 0.420 & 0.097 & 0.235 \\
\hline $2101-2300 \mathrm{~nm}$ & 0.013 & 0.334 & 0.009 & 0.001 & 0.015 & 0.104 & 0.900 & 0.007 & 0.068 \\
\hline IMAGE level & N.S.-C.V. & N.S.-M.C. & C.V.-M.C. & N.S.-C.V. & N.S.-M.C. & C.V.-M.C. & N.S.-C.V. & N.S.-M.C. & C.V.-M.C. \\
\hline $400-500 \mathrm{~nm}$ & 0.000 & 0.003 & 0.000 & 0.000 & 0.000 & 0.001 & 0.000 & 0.000 & 0.383 \\
\hline $501-600 \mathrm{~nm}$ & 0.000 & 0.007 & 0.000 & 0.000 & 0.000 & 0.037 & 0.000 & 0.000 & 0.048 \\
\hline $601-680 \mathrm{~nm}$ & 0.000 & 0.001 & 0.000 & 0.000 & 0.000 & 0.057 & 0.000 & 0.000 & 0.000 \\
\hline $681-800 \mathrm{~nm}$ & 0.000 & 0.167 & 0.000 & 0.000 & 0.000 & 0.195 & 0.001 & 0.000 & 0.000 \\
\hline $801-1000 \mathrm{~nm}$ & 0.000 & 0.225 & 0.000 & 0.000 & 0.002 & 0.075 & 0.316 & 0.000 & 0.000 \\
\hline
\end{tabular}

Table 1. Median p-values of Welch's (unpaired) t-test for each species (C.V. - Calamagrostis villosa, M.C. - Molinia caerulea, N.S.

- Nardus stricta), spectral measurement method and date for selected spectral intervals. P-value $<0.05$ means that significant

difference between species exists (green scale); non-separable intervals of the wavelengths are indicated in red scale.

\section{CONCLUSIONS}

Our study showed that for each combination of species (Calamagrostis villosa, Molinia caerulea and Nardus stricta) and each spectra level a suitable date and intervals of the spectral bands for the separation exist. Nevertheless, the results differ for the three data sources. At the leaf level (spectral measurements with the contact probe in the laboratory), the most suitable date for differentiating all the species is July (a peak of the growing season) and near-infrared and shortwave infrared spectral ranges. At the canopy (spectral measurements in the field) and image levels $(3 \mathrm{~cm}$ data acquired by Headwall Nano-Hyperspec $(\mathbb{R})$ visible bands are of higher importance for differencing the species. This indicates that data acquired for the area of the Krkonoše Mts. even using just RGB camera or multispectral sensor (from UAV) might be sufficient to distinguish the three evaluated grass species.

For the canopy and image levels more similarities in the species separation during the season were observed. In contrast to the green leaf level, at the canopy and image levels the necromass (very abundant especially at the beginning of the season in June), height of grass and its shadows play an important role in spectral reflectance.

\section{ACKNOWLEDGEMENTS}

This research was made possible by Ministry of Education of the Czech Republic, project LTAUSA18154: Assessment of ecosystem function based on Earth observation of vegetation quantitative parameters retrieved from data with high spatial, spectral and temporal resolution. The support by Charles University (UNCE/HUM 018) is also acknowledged.

\section{REFERENCES}

Beamish, A., Coops, N., Chabrillat, S., Heim, B., 2017: A Phenological Approach to Spectral Differentiation of LowArctic Tundra Vegetation Communities, North Slope, Alaska. Remote Sens. 9, 1200. doi.org/10.3390/rs9111200

Bratsch, S., Epstein, H., Buchhorn, M., Walker, D., 2016: Differentiating among Four Arctic Tundra Plant Communities at Ivotuk, Alaska Using Field Spectroscopy. Remote Sens. 8, 51. doi.org/10.3390/rs8010051

Červená, L., Lysák, J., Potůčková, M., Kupková, L., 2020. Zkušenosti se zpracováním hyperspektrálních dat pořízených UAV. Presented at the Symposium GIS Ostrava 2020: Prostorová data pro Smart City a Smart Region, Vysoká škola báňská - Technická univerzita Ostrava, Ostrava. doi.org/10.31490/9788024843988-4

Davidson, S., Santos, M., Sloan, V., Watts, J., Phoenix, G., Oechel, W., Zona, D., 2016: Mapping Arctic Tundra Vegetation Communities Using Field Spectroscopy and Multispectral Satellite Data in North Alaska, USA. Remote Sens. 8, 978. doi.org/10.3390/rs8120978

Hejcman, M., Češková, M., Pavlů, V., 2010: Control of Molinia caerulea by cutting management on sub-alpine grassland. Flora - Morphol. Distrib. Funct. Ecol. Plants 205, 577-582. doi.org/10.1016/j.flora.2010.04.019 
Hejcman, M., Klaudisová, M., Hejcmanová, P., Pavlů, V., Jones, M., 2009: Expansion of Calamagrostis villosa in subalpine Nardus stricta grassland: Cessation of cutting management or high nitrogen deposition? Agric. Ecosyst. Environ. 129, 91-96. doi.org/10.1016/j.agee.2008.07.007

Kociánová, M., Štursa, J., Vaněk, J., 2015: Krkonošská tundra. Správa Krkonošského národního parku, Vrchlabí.

Kubát, K., Bělohlávková, R. (Eds.), 2002. Klič ke květeně České republiky, Vyd. 1. ed. Academia, Praha.

Kupková, L., Červená, L., Suchá, R., Jakešová, L., Zagajewski, B., Březina, S., Albrechtová, J., 2017: Classification of Tundra Vegetation in the Krkonoše Mts. National Park Using APEX, AISA Dual and Sentinel-2A Data. Eur. J. Remote Sens. 50, 29 46. doi.org/10.1080/22797254.2017.1274573

Marcinkowska-Ochtyra, A., Zagajewski, B., Raczko, E., Ochtyra, A., Jarocińska, A., 2018: Classification of HighMountain Vegetation Communities within a Diverse Giant Mountains Ecosystem Using Airborne APEX Hyperspectral Imagery. Remote Sens. 10, 570. doi.org/10.3390/rs10040570

Soukupová, L., Kociánová, M., Jeník, J., Sekyra, J., 1995: Arctic alpine tundra in the Krkonoše, the Sudetes. Opera Corcon. 32, 5-88.

Štursa, J., Wild, J., 2014: Kleč a smilka - klíčoví hráči vývoje alpínského bezlesí Krkonoš (Vysoké Sudety, Česká republika). Opera Corcon. 51, 5-36.

Suchá, R., Jakešová, L., Kupková, L., Červená, L., 2016: Classification of vegetation above the tree line in the Krkonoše Mts. National Park using remote sensing multispectral data. AUC Geogr. 51, 113-129. doi.org/10.14712/23361980.2016.10

Treml, V., Ponocná, T., Büntgen, U., 2012: Growth trends and temperature responses of treeline Norway spruce in the CzechPolish Sudetes Mountains. Clim. Res. 55, 91-103. doi.org/10.3354/cr01122

Vítek, O., Vítková, M., Müllerová, J., 2012: Anthropogenic changes of vegetation above timberline in the Krkonoše Mountains National Park focusing on the impact of tourism. Opera Corcon. 49, 5-30. 